\title{
Analysis of Recycling Plastic Waste Activities as AQUA's Corporate Social Responsibility Program
}

\author{
Dini Nur Amalina, Ummi Salamah \\ Fakultas Ilmu Sosial dan Ilmu Politik, Universitas Indonesia, Jakarta, Indonesia \\ Dininuramalina@gmail.com (Dini Nur Amalina),Ummisalamah@yahoo.com (Ummi Salamah)
}

\begin{abstract}
In this technological development era, companies need to pay more attention to the environment and the surrounding community in order to avoid the various demands put forward by the public due to the impact of company's production in running its business. The classical economic doctrine, "maximization profit", which the main goal of the company is to lower costs as low as possible and increase efficiency as high as possible in order to maximize profits, then shifted into a new paradigm, namely how companies need to create a "positive image" to its stakeholders. One way that companies do to form a positive image is the procurement of Corporate Social Responsibility program. Qualitative descriptive analysis method is used in this research to clearly describe the problems that exist in the object of research which will eventually be seen related to the related theories. The result showed that the Corporate Social Responsibility program in the form of recycling plastic waste activities conducted by AQUA Group is in line with the concept of CSR definition, which is to minimize negative impact and maximize the positive impact of its operation to all stakeholders in economic, social and environmental aspect in order to achieve the goal Sustainable development. In addition, recycling plastic waste activities conducted by AQUA Group also contains three bottom lines of the concept of corporate social responsibility, namely Profit, People, and Planet.
\end{abstract}

\section{Keywords Corporate Social Responsibility, Organizational Communication, Environment, Recycle}

\section{Introduction}

In general, the management of natural resources in Indonesia is based more on efforts to meet investment needs in the framework of economic recovery. This policy describes that the management of natural resources is more viewed and understood within the context of economic sense and has not led to ecological and sustainable sense (Azheri, 2011: 1). The condition proves that many companies adhere to the classical economic doctrine, "maximization profit", as stated by Adam Smith who asserted that "the main goal of the company is to reduce costs as low as possible and increase efficiency as high as possible in order to maximize profit". Unfortunately, companies with profit-oriented economic behavior often ignore the welfare of local communities, workers and environmental degradation. Along with the development of the era, the doctrine is considered no longer relevant to be implemented in the current world conditions. There will be many demands from an increasingly environmentally conscious society if the company retains the classical economic doctrine. Therefore, the classical paradigm shifted into a new paradigm, namely how companies need to create a "positive image" to its stakeholders by the implementation of Corporate Social Responsibility (CSR) program.
Theoretically, CSR is the core of business ethics. A company not only has economic and legal liabilities to shareholders, but also has obligations to other stakeholders. All of that can not be separated from the fact that a company can not live, operate, survive and gain benefits without the help of various parties (Azheri, 2011: 5). According to Indonesian learning association of CSR (Rachman, Efendi, and Wicaksana, 2011: 15), CSR is the earnest effort of the business entity to minimize negative impacts and maximize the positive impact of its operations on all stakeholders in the economic, social and environmental in order to achieve sustainable development goals. For a company that consistently implements CSR in its activities, in the long run it will gain profit in the form of trust from its stakeholder (corporate image). This condition has become a serious concern from business circles both domestic and international. The facts indicate a positive correlation between companies that implement CSR in their business activities with public appreciation. Therefore, the implementation of CSR is no longer considered as a "cost", but rather as a long-term investment for the company concerned.

AQUA Group is one of the companies that implement Corporate Social Responsibility. AQUA Group is a market leader in meeting the consumer needs of bottled drinking water (AMDK) products in Indonesia. Considering the AQUA Group's products based on water resources, the main challenge faced is sustainability, followed by social and 
economic impacts. To deal with the situation, AQUA Group launched the AQUA Lestari program by inviting stakeholders (companies, governments, communities) to engage in greater efforts to safeguard the environment and contribute to improved quality of life. AQUA Lestari is AQUA Group's commitment to always manage the environment, with integrated social initiatives from the upstream, middle and downstream areas of the AQUA Group location. AQUA Lestari is committed to maintaining a balance between business and environmental sustainability and community progress. There are four pillars run by AQUA Lestari, Preservation of Water and the Environment, Green Practices, Management of Product Distribution, Community Involvement and Empowerment(http://aqua.com/aqua_lestari). One program of AQUA Lestari's "Green Practices" that is implemented by AQUA Group is recycling plastic waste activities.

Referring to the recycling plastic waste activities, researcher want to know in depth how the implementation of Corporate Social Responsibility conducted by AQUA Group and its relevance to the concepts of CSR, especially the Triple Bottom Line concept. In addition, researcher want to see what are the benefits of AQUA Group from the implementation of Corporate Social Responsibility in the form of recycling plastic waste activities.

\section{Theory and Concept}

\section{Corporate Social Responsibility}

One of the most interesting definitions of Corporate Social Responsibility is from Indonesian learning association of CSR, "The earnest effort of the business entity to minimize negative impacts and maximize the positive impact of its operations on all stakeholders in the economic, social and environmental in order to achieve sustainable development goals". Meanwhile, according to Philip Kotler, CSR is said to be discretionary which in the broad sense means something that needs to be done. If it had not been done, it would have hurt. According to the World Business Council for Sustainable Development, CSR is not merely discretionary, but a commitment that is wholesome for a good company as an improvement of life quality. Philosophically, if the company tries to be useful for mankind then in the long run will certainly still exist (Rachman, Efendi and Wicaksana, 2011: 15).

In providing benefits, companies need to have priorities and strategies. One of the most important priorities is the existence of the company itself to become a sustainable business entity (the ability to generate long-term profits). This will certainly be a strategic goal. The ability to generate long-term profit will only be realized if the company's presence can be useful and supported by stakeholders. Stakeholder support will be realized if negative impacts on the social, economic, and environmental aspects are not only minimized but can have a great positive impact on stakeholders.

\section{Triple Bottom Line Concept}

According to John Elkington (Rachman, Efendi and Wicaksana, 2011: 10), the concept of corporate social responsibility is based on three basic principles known as triple bottom lines or 3P. This concept formulates that the sustainability and growth of the company does not depend on the profit (profit), but also the actual actions that companies do to the environment (the planet), and justice (people). The goal is to create sustainable development. The three components of triple bottom line are dynamic depending on social, political, economic, and environmental conditions and pressures. Here's a description of the triple bottom line concept:

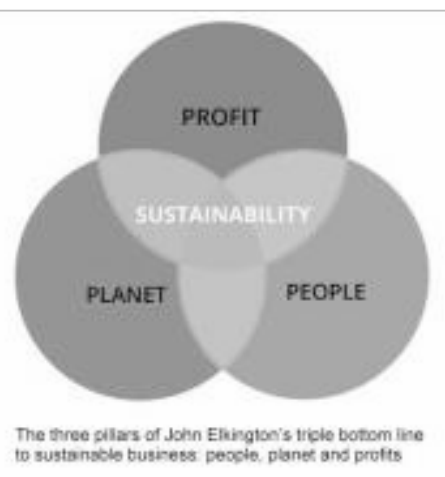

Figure 1. The Three pillars of John Elkington's triple bottom line

1) Profit. Companies must remain oriented to seek economic benefits that allow it to continue to operate and grow.

2) People. Companies must have awareness of human welfare. Some companies develop corporate social responsibility programs, such as scholarships for students around the company, establishing educational and health facilities, strengthening local economic capacity, and even some companies designing various social protection schemes for local residents.

3) Planet. Companies are concerned about the environment and sustainable biodiversity. Some of the corporate social responsibility programs that are based on this principle are the greening of the environment, the provision of clean water facilities, the improvement of settlements and the development of tourism (ecotourism).

\section{Method}

The method used in this study is descriptive qualitative to clearly describe the problems that exist in the object of research by using a deductive way of thinking and to see the relation between object of research and related theories. This study is done with analysis of secondary data to various documents, which are internal document in form of AQUA's company data, announcement, instruction, implementation standard, and Corporate Social Responsibility rules, also obtained from external data, in the form of reports issued by an institution, news broadcasted by mass media about AQUA and object of research. 


\section{Kesult and Discussion}

For the industry, including AQUA, packaging is an essential component of maintaining nutrients and product quality to the point of the consumer. However, plastic packaging that is not managed properly is potentially a waste that can contaminate the oceans. Currently an estimated 150 million tons of plastic waste is scattered in the oceans. This amount certainly will not decrease by itself. According to the report "The New Plastics Economy" from the Ellen MacArthur Foundation, in 2050 the amount of waste in the ocean will exceed the total population of fish (https://www.ellenmacarthurfoundation.org/publications/the -new-plastics-economy-rethinking-the -future-of-plastic). Regarding to the management of plastic waste, various parties such as government, private, and community have equal roles and responsibilities to minimize the negative impact of product packaging.

To deal with the situation, AQUA Group launched the AQUA Lestari program by inviting stakeholders (companies, governments, communities) to engage in greater efforts to safeguard the environment and contribute to improved quality of life. AQUA Lestari is AQUA Group's commitment to always manage the environment, with integrated social initiatives from the upstream, middle and downstream areas of the AQUA Group location. AQUA Lestari is committed to maintaining a balance between business and environmental sustainability and community progress. There are four pillars run by AQUA Lestari, Preservation of Water and the Environment, Green Practices, Management of Product Distribution, Community Involvement and (http://aqua.com/aqua_lestari).

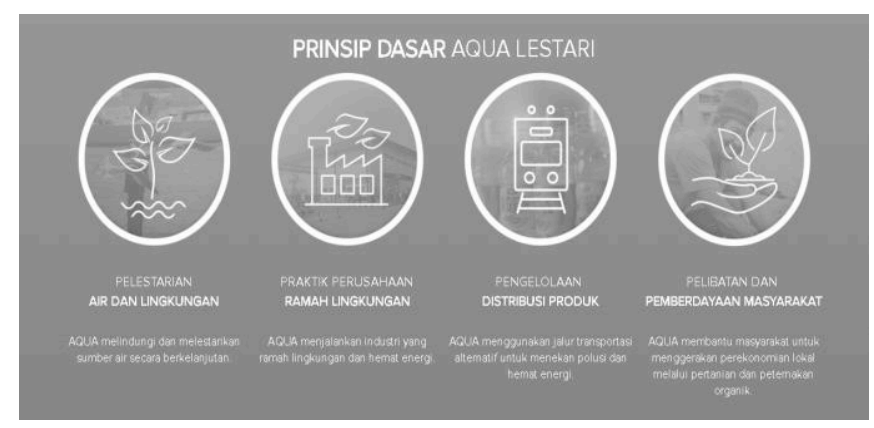

Figure 2. The Four pillars of AQUA Lestari (http://aqua.com/aqua_lestari)

Implementing one of Aqua Lestari's "Green Practices" pillar, AQUA Group as part of Danone's business unit, took a gradual step in adopting Danone's five commitments to realize a circular economy, which are:

1. Using sustainable resources

By 2020, Danone aims to eliminate the use of paper based packaging derived from unsustainable sources such as deforested areas. Danone is also committed to the bio-economy and the use of bio-sourced plastic materials. Danone's new innovations in plant based plastic are thanks to the work of the Bioplastic Feedstock Alliance, co-created with the WWF.

2. Packaging weight optimization
Danone continues to reduce the amount of packaging that is used while ensuring it still brings the ideal and most qualitative consumer experience. Danone's R\&D teams work to deliver new innovations and to help make $100 \%$ of Danone's packaging fully recyclable.

3. Eliminating industrial plastic waste to the final disposal site (TPA)

To keep the environment, especially the final disposal site, from plastic waste that can not be recycled, AQUA builds a system to ensure traceability and create a new life cycle for waste generated during the post-production process.

4. Engaging consumers to recycle

The circular economy starts with consumers and Danone's packaging is the first communication contact with them. Danone therefore use their packaging to encourage consumers to adopt responsible and recycling behaviors, and use their creativity and marketing ability to make recycling common practice.

5. Creating a new cycle of packaging plastic waste Danone's goal is to actively contribute to create a second-life for all plastics Danone use. In countries where waste collection is based on the informal sector, Danone will continue to build coalitions to experiment innovative and socially inclusive recycling models (http://www.danone.com/en/for-all/sustainability/bette r-world/packaging).

In relation to the first commitment is using sustainable resources. Danone has built alliances with other research and consumer goods companies. The alliance is in the form of research on the packaging of plastic bottles which $100 \%$ based on sustainable resources. Associated with the second commitment which is packaging weight optimization, AQUA is gradually reducing packaging weight and eliminating plastic seals from all product lines to realize a $100 \%$ circularly designed packaging. AQUA also implement an empty gallon exchange system and regain process to recycle unfit gallon packaging. AQUA ensures that all components of product packaging can be recycled by replacing PVC raw materials for SPS label products with BOPP. The third commitment is to eliminate industrial plastic waste to the final disposal site (TPA) by building a system to ensure traceability and create a new life cycle for waste generated during the post-production process. AQUA also develops waste banks at the school as part of fulfilling the fourth commitment to facilitate consumers in using packaging as well as education of segregation and recycling of packaging waste. To fulfil the fifth commitment in creating a new cycle of packaging plastic waste, AQUA also initiated the Recycling Business Unit (RBU) in 2010 in South Tangerang. RBU AQUA employs more than 44 employees who are entitled to BPJS health insurance collecting plastic bottles, cleaning and managing the waste into flakes. The production of plastic counts in one year reaches 900 tons and is then sold to the recycling industry and processed into raw materials of new products such as textile yarns, t-shirts, dakron, geotextiles, straps, and so on. "RBU is built with a social business model to attract plastic bottles for recycling," explains Karyanto Wibowo, Director of Sustainable Development of Danone Indonesia. "Thus the plastic life 
cycle does not stop when consumers throw the bottle away, but it continues into other creative stuff," he added.

AQUA also cooperates with PT. Namasindo PLAS Indonesia to build RBU in Tohpati, Denpasar City to increase waste management capacity. Following in 2011, AQUA also established RBU Pantai Lepang, Klungkung District. Both RBU has produced 400 Ton flakes every month. In 2013, both RBUs are transferred to Bali PET. AQUA itself still contributes to financing scavengers' health and employees in both RBU. While in Bandung, AQUA's partner network also built RBU with garbage up to 6000 Ton / year. AQUA's ambition to increase the capacity of plastic waste also encourages the network of waste networks in Bogor and Jakarta. In collaboration with CV Maximum and the Bogor City Government, AQUA initiated the formation of the Garbage Bank which plays a role in the collection of plastic bottle packaging from 12 small scale waste banks and TPS3R located in Bogor City to be brought to RBU in Tangsel. Until the end of 2016, plastic bottles are brought to Tangsel RBU has reached 7 tons. The RBU also received 13 tons of plastic bottles from the Jakarta Municipal Garbage Bank. The amount is obtained from a network of 10 waste banks based on community empowerment, 5 temporary garbage disposal sites, and 10 collectors, including a network of collectors in Kepulauan Seribu. Karyanto said that AQUA will continue to increase the amount of plastic bottles waste for recycling. "Recycling will reduce the rate of waste in the landfill and the decline of waste in the oceans," Karyanto added.

AQUA is actively engaged in cooperation with stakeholders in the field of waste and recycling including with corporations such as PT Coca-Cola Indonesia, PT Indofood Sukses Makmur Tbk, PT Nestle Indonesia, PT Tetra Pak Indonesia and PT Unilever Indonesia through the establishment of PRAISE (Packaging and Recycling Alliance for Indonesia Sustainable Environment / Alliance for Packaging and Recycling for Sustainable Indonesia). The Alliance carries the concept of an Extended Stakeholder Responsibility (ESR) framework. ESR emphasizes the important role of government, private, and community to establish collaboration in waste management. Each party has roles and responsibilities in the waste management cycle ranging from timber restrictions, recycling, reuse, to waste management including segregation, collection, transport, processing and final processing. Handling waste is a series of activities that are long and too heavy to be charged to one party. "Examples of best practices of stakeholder collaboration in waste management are what we do in Bali," Karyanto said.

On February 19, 2017, AQUA and Tetra Pak launched the Drop Box, a bottle-shaped packaging product bins. Drop Box is a working group collaboration project initiated by the Ministry of Environment and Forestry (KLHK) to reduce packaging waste in Bali. The working group consists of the Sarbagita, Badung, Tabanan, Gianyar, Denpasar City Government, Association of Indonesian Retail Entrepreneurs (APRINDO), restaurants, Recycling Entrepreneurs (Bali PET, Eco Jos, REPAL, etc.), LSM Eco Bali, Bank Sampah, TPS3R, AQUA, and Tetrapak. Stakeholders carry out their respective roles and functions. The local government facilitates through regulations on waste processing while producers, in this case AQUA and Tetra Pak facilitate the making of Drop Box and coordinate with waste recyclers (Bali Pet and Eco Bali) to transport the collected garbage for recycling. Retail entrepreneurs provide a place to put Drop Box in the outlet network as well as educate consumers who visit.

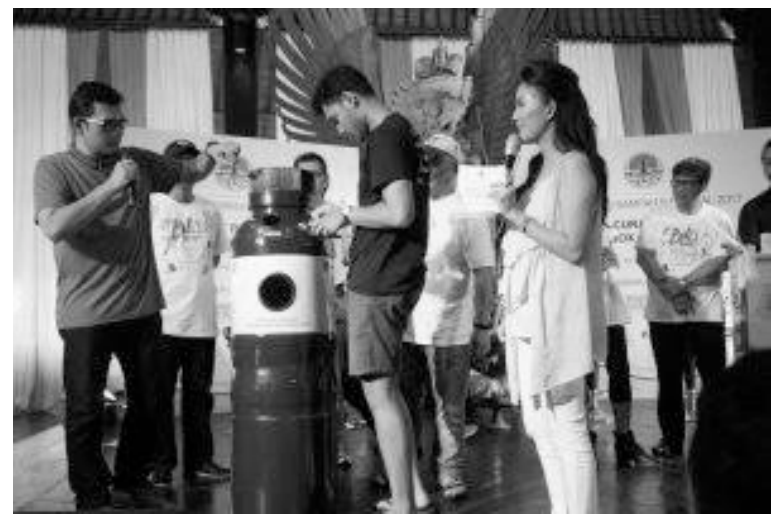

Figure 3. AQUA and Tetra Pak's Drop Box Launching Event (https://jarbatnews.com/nasional/aqua-grup-luncurkan-drop-box-sampah-k emasan-air-minum/)

Drop Box deliberately designed with a unique shape and placed in a retail outlet network to facilitate and familiarize the public to put packaging in place. The community's active participation not only helps eliminate packaging waste but also has an impact on increasing the level of garbage collection for recycling. Communities should always be involved in the waste management process. In addition, the government and the private sector are expected to continue to build public awareness through creative and innovative steps.

AQUA received an award from the Ministry of Environment and Forestry for the Waste Reduction Performance category at the National Rubbish Removal Day celebration of 2017 for the Company's overall effort to reduce waste.

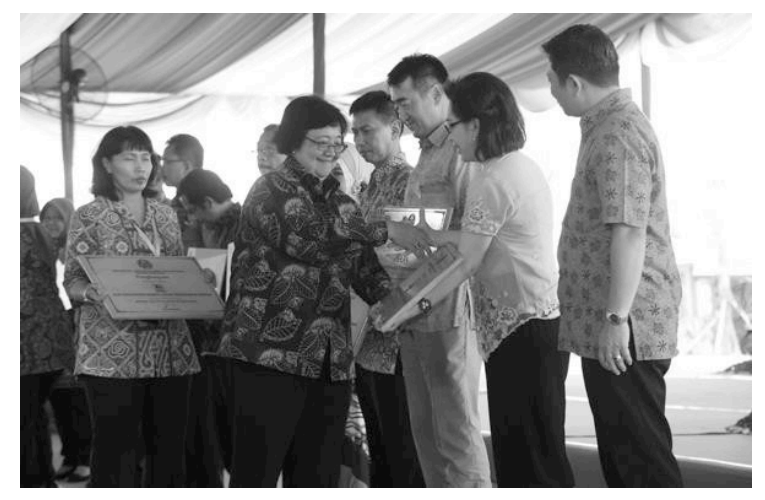

Figure 4. AQUA received an award from the Ministry of Environment and Forestry at the National Rubbish Removal Day celebration of 2017 (http://www.aqua.com/kabar_aqua)

The Ministry of Environment and Forestry selected 13 manufacturing and retail companies that have been responsible for carrying out waste management. Selection 13 companies are then divided based on two categories of awards, namely corporate performance and corporate initiatives. The process of selection is ranging from filling ques- 
tionnaires, document verification, field review and final presentation

VP Danone Indonesia's General Secretary, Leila Djafaar, said the award for the company in managing plastic waste from The Ministry of Environment and Forestry is the second time for AQUA Group. In 2016, AQUA Group received awards from the Ministry of Environment and Forestry on its initiative to manage packaging waste.

"This year, AQUA Group is included in four selected companies considered to have Performance as Producers in Waste Management. AQUA Group was selected in the final process due to the addition of point of garbage collection location after managing three Recycling Business Units (RBU) in Tangerang Selatan, Bali and Bandung. AQUA Group works with several parties to build a network for PET garbage collection. This network involves Bank Sampah and lapak in Bogor and Jakarta" (http://www.antaranews.com/berita/615186/menteri-lhk-ber i-penghargaan-pengelolaan-sampah-terbaik)

It can be seen that AQUA's plastic waste processing program is in line with the definition of Corporate Social Responsibility from Indonesian learning association of CSR, "The earnest effort of the business entity to minimize negative impacts and maximize the positive impact of its operations on all stakeholders in the economic, social and environmental in order to achieve sustainable development goals" (Rachman, Efendi and Wicaksana, 2011: 15). In order to minimize the negative impacts of product packaging as well as the company's operations, AQUA Group with the help of stakeholders, both from corporations, governments and the public, makes greater efforts to protect the environment and contribute to improving the quality of life by implementing recycling plastic waste activities.

Referring to the five commitments undertaken by AQUA, it can be seen that in this recycling plastic waste activities, there are three basic principles (Profit, People and Planet) expressed by John Elkington. AQUA as a company does not forget its purpose to seek economic benefits that allow it to continue to operate and develop. Therefore, AQUA builds alliances with other research and consumer goods companies to research about plastic bottle packaging based on $100 \%$ sustainable resources so that the company can continue to run without damaging and eliminating existing resources. This goes into the basic principles of Profit. In relation to the basic principles of People, where companies have to care for human well-being, AQUA takes care of people's welfare by employing more than 44 employees at the Recycling Business Unit in Tangerang Selatan and many employees in other RBUs and cover all the employees with BPJS health insurance for collecting plastic bottles, cleaning up, and managing the waste into flakes. AQUA Group itself is still contributing to scavenger healthcare and employees' financing in RBUs managed by AQUA. The basic principle of the Planet, where companies need to care for the environment and sustainable biodiversity, is implemented by AQUA Group in this plastic program by building a Recycling Business Unit (RBU) where the process of collecting plastic bottles, cleaning and managing of the waste into plastic shards (flakes) is held. The production of this plastic replica will be sold to recycling industry players and processed into raw materials of new products such as textile yarn, t-shirts, dakron, geotextiles, straps, and so on. Karyanto Wibowo, Director of Sustainable Development of Danone Indonesia, said that by doing plastic waste processing the plastic life cycle does not stop when consumers throw the bottle away, but it continues into other creative items. In addition, the recycling process will reduce the rate of waste in the landfill and reduce waste in the oceans that will impact on environmental sustainability.

\section{Conclusion}

The change of classical economic paradigm, which the main goal of the company is to lower costs as low as possible and increase efficiency as high as possible in order to maximize profits, to be a new paradigm, that is how companies need to create a "positive image" to their stakeholders, encourage AQUA Group to conduct an activity that organizations use to recognize, understand and influence the public associated with the organization. One of them is the Corporate Social Responsibility program in the form of Recycling plastic waste activities.

In practice, these recycling plastic waste activities are assessed in line with the CSR definition of the Indonesian learning association of CSR, namely "The earnest effort of the business entity to minimize negative impacts and maximize the positive impact of its operations on all stakeholders in the economic, social and environmental in order to achieve sustainable development goals ". This is evidenced by the AQUA Group's efforts to minimize negative impacts by using sustainable feedstock to create a new life cycle for plastics.

From table 1, it describes that in this recycling plastic waste activities is contained three pillars of John Elkington's triple bottom line namely Profit, People, and Planet.

Table 1. Three bottom lines concept of AQUA's Corporate Social Responsibility Program

\begin{tabular}{|c|c|c|}
\hline The Pillar & Description & Implementation \\
\hline Profit & $\begin{array}{l}\text { A company } \\
\text { does not forget } \\
\text { its purpose to } \\
\text { seek economic } \\
\text { benefits that } \\
\text { allow it to } \\
\text { continue to } \\
\text { operate and } \\
\text { grow }\end{array}$ & $\begin{array}{l}\text { AQUA builds alliances } \\
\text { with other research and } \\
\text { consumer goods com- } \\
\text { panies to research about } \\
100 \% \text { sustainable re- } \\
\text { sources so that the } \\
\text { company can continue } \\
\text { run without damaging } \\
\text { and eliminating existing } \\
\text { resources }\end{array}$ \\
\hline People & $\begin{array}{l}\text { A company } \\
\text { must have } \\
\text { concern for the } \\
\text { welfare of } \\
\text { human beings }\end{array}$ & $\begin{array}{l}\text { AQUA is employing } \\
\text { more than } 44 \text { employees } \\
\text { at the Recycling Busi- } \\
\text { ness Unit in Tangerang } \\
\text { Selatan and many em- } \\
\text { ployees in other RBUs } \\
\text { which are entitled to } \\
\text { health insurance BPJS } \\
\text { to collect waste plastic } \\
\text { bottles, clean up, and } \\
\text { manage the waste into } \\
\text { flakes. AQUA Group } \\
\text { itself is still contributing }\end{array}$ \\
\hline
\end{tabular}


Table 1. cont.

\begin{tabular}{l|l}
\hline & $\begin{array}{l}\text { to scavenger healthcare } \\
\text { and employees' financ- } \\
\text { ing in RBUs managed } \\
\text { by AQUA. }\end{array}$ \\
\hline & $\begin{array}{l}\text { AQUA builds a Recy- } \\
\text { cling Business Unit } \\
\text { (RBU) where the pro- } \\
\text { cess of collecting plastic } \\
\text { bottles, cleaning and } \\
\text { managing of the waste } \\
\text { into plastic shards } \\
\text { (flakes) is held. The } \\
\text { production of this plas- } \\
\text { needs to care } \\
\text { for the envi- } \\
\text { ronment and } \\
\text { sustainable } \\
\text { biodiversity }\end{array}$ \\
$\begin{array}{l}\text { recycling industry } \\
\text { players and processed } \\
\text { into raw materials of } \\
\text { new products such as } \\
\text { textile yarn, t-shirts, } \\
\text { dakron, geotextiles, } \\
\text { straps, and so on }\end{array}$ \\
\end{tabular}

It is expected that in the future AQUA Group can continue to maintain its good relationship with its stakeholders by inviting stakeholders (companies, governments, communities) to engage in greater efforts to safeguard the environment and contribute to improving the quality of life so that AQUA Group continues to be a sustainable business and gain high trust from its stakeholders. It is also expected for other companies to participate in implementing Corporate Social Responsibility program to create a balance between business, environmental sustainability and community progress and achieve sustainable development goals.

[8]

\section{REFERENCES}

[1] AQUA Group. Commitment for Indonesia: Sustainability Report. 2013-2014

[2] Azheri, Busyra. Corporate Social Responsibility: Dari Voluntary Menjadi Mandatory. Jakarta: RajaGrafindo Persada. 2012.

[3] Goldhaber, Gerald M. Organizational Communication. Dubuque Iowa: Wm. C. Brown. 1993.

[4] Rachman, M Nurdizal. Efendi, Asep dan Wicaksana, Emir. Panduan Lengkap Perencanaan CSR. Depok: Penebar Swadaya. 2011.

[5] http://www.antaranews.com/berita/615186/menteri-lhk-beripenghargaan-pengelolaan-sampah-terbaik

[6] http://aqua.com/aqua_lestari/article/single/olah-sampah-plast ik-aqua-raih-penghargaan-dari-kementrian-lingkungan-hidu p-dan-kehutanan-2

[7] http://www.aqua.com/kabar_aqua/siaran-pers/kementerian-li ngkungan-hidup-dan-2 http://www.aqua.com/kabar_aqua/berita-perusahaan/aqua-te rima-penghargaan-inisiatif

[9] http://aqualestari.aqua.com/article/single/rbu-tangerang-selat an-bantu-hidupkan-kembali-bank-sampah-mekarsari/

[10] http://www.aqua.com/kabar_aqua/siaran-pers/aqua-kerahkan -karyawan-dan-1

[11] http://aqua.com/kabar_aqua/siaran-pers/peringati-hari-peduli -sampah

[12] http://www.danone.com/en/for-all/sustainability/better-worl d/packaging/

[13] https://jarbatnews.com/nasional/aqua-grup-luncurkan-drop-b ox-sampah-kemasan-air-minum/ 